\author{
П. Гуйван, \\ кандидат юридичних наук, Заслужений юрист України, \\ професор \\ Полтавського інституту бізнесу \\ Міжнародного науково-технічного університету імені академіка Юрія Бугая
}

\title{
ДОТРИМАННЯ ЄВРОПЕЙСЬКИХ ПРИНЦИПІВ ПРОПОРЦИИНОСТІ - ГОЛОВНА ЗАСАДА ГАРАНТІЇ ПРАВА НА ВІЛЬНЕ САМОВИРАЖЕННЯ
}

Демократичний розвиток суспільства, гармонійний поступ кожної особистості не можливі без інформаційної свободи кожної людини. Європейська конвенція про захист прав людини i основоположних свобод, конституційні закони цивілізованих країн гарантують право на свободу вираження поглядів та свободу інформації. Але в основних міжнародно-правових актах, конвенціях інформаційні права i свободи, як i інші права людини, проголошуються в загальному, декларативному вигляді. Тому велике значення для практичного здійснення особою інформаційних прав має практика застосування та захисту інформаційних прав людини на універсальному рівні (Комітетом ОOH з прав людини) та регіональному рівні (Міжамериканським і Європейським судами 3 прав людини тощо). Така практика $€$ інструментом конкретизації і реалізації інформаційних відносин, що істотно впливає на розвиток міжнародного інформаційного права, його доктрини і практики.

Право на свободу слова не є безмежним. Обмеження права на вільне вираження поглядів не $є$ порушенням конвенції, якщо ці обмеження встановлені для досягнення однієї з цілей, зазначених у пункті 2 статті 10 цього міжнародного акту. Зокрема, вказана норма передбачає, що здійснення свободи вираження думок, ідей і поглядів, оскільки воно пов'я- зане з обов'язками і відповідальністю, може підлягати таким формальностям, умовам, обмеженням або санкціям, які необхідні в демократичному суспільстві та встановлюються законом в інтересах національної безпеки, територіальної цілісності або громадської безпеки для запобігання заворушенням чи злочинам, для охорони здоров'я чи моралі, для захисту репутації чи прав інших осіб, для запобігання розголошенню конфіденційної інформації або для підтримання авторитету і безсторонності суду.

Конвенційні та конституційні приписи визначають певний виключний перелік важливих для держави, суспільства і конкретної людини сторін життєдіяльності, яким може бути нанесена шкода зловживанням правом на свободу слова. Але такий перелік має хоча і обмежений, але всередині дуже аморфний зміст. Тож, щоб правильно застосовувати вказане державне втручання, не допускаючи сваволі та суб'єктивізму, мають бути чітко визначені критерії та межі подібного владного впливу. Це важливо саме тому, що втручання відбувається в основоположне право людини - на інформацію, що забезпечує належну реалізацію всіх інших іï прав і свобод. Українська національна правова доктрина та правозастосовна практика не напрацювали єдиних підходів до регулювання вказаних питань. 
Часто зовсім полярними виглядають оцінки пересічних громадян, фахівців і представників влади тих протилежних за сутністю і змістом суспільних та приватних інтересів, які при цьому стикаються. Скажімо, публічний інтерес у самовираженні кожної особи, який реалізується через можливість кожного суб'єкта, включаючи 3MI, доводити до відома оточуючих свої політичні та інші переконання, думки, ідеї, досить часто вступає у протиріччя з державними правилами щодо охорони конфіденційної чи секретної інформації, може порушувати громадську безпеку тощо.

Вільне вираження думок може порушити приватне право конкретної людини на конфіденційність іï особистих даних і заподіяти особі матеріальних та моральних збитків. Враховуючи важливість питання та той факт, що проблематика носить міжнародний характер, реалізація правового забезпечення іiі винесена на якісно новий і досить високий рівень.

Європейський суд з прав людини як інституція, покликана в практичній площині вирішувати завдання, поставлені конвенцією, встановив і напрацював критерії правомірності обмежень права на свободу вираження поглядів, що накладаються органами державної влади. Вони застосовуються щоразу самим судом, коли він вирішує реальний спір між заявником і конкретною державою-відповідачем. Крім того, будучи продуктом прецедентного правозастосування, подібне рішення має враховуватися різними легіслатурами та правозастосовними системами при формуванні власного законодавства та практики судівництва.

У науковій літературі питанням щодо ефективності та співмірності використання права на свободу слова учасниками інформаційних відносин присвячені праці Н. Корченкова, Ю. Барабаш, О. Жуковської, Н. Лернер, В. Цимбалюк, Е. Тітко, С. Шевчук та інших.
Ця проблематика $є$ досить актуальною і потребує більш детальних досліджень окремих важливих аспектів. Зокрема, не досить вивченими $€$ питання пропорційності владного втручання в свободу вираження, насамперед з огляду на суспільну прийнятність таких заходів та їхню необхідність у демократичному суспільстві. Також повинен бути визначений необхідний критерій для знаходження балансу, який би гарантував прийнятність втручання у інформаційну свободу з боку владних інституцій та механізми його правового обмеження. Вказані питання потребують підвищеного рівня захисту.

Метою статті $є$ дослідження фактичного стану відносин щодо гарантування вираження та поширення інформації та вироблення конкретних рекомендацій, спрямованих на відтворення практики Європейського суду в українському правовому середовищі.

Виклад основного матеріалу. Відносини в сфері інформаційної свободи, включаючи ті, що стосуються права отримувати відомості та мати доступ до інформації, $є$ семантично близькими до тих, які забезпечують можливість висловлювати власну думку. I ті, й інші спрямовані на визначення ролі суб'єктів, об'єктів і ресурсів, які входять в інформаційну сферу, будь-то засоби масової інформації, телекомунікаційні мережі, віртуальний простір на основі інтернету або будь-які інші елементи сучасної інформаційної інфраструктури.

Національні владні і суспільні інституції тісно співпрацюють у цьому напрямі 3 міжнародними організаціями. Так, спільна програма Європейського Союзу та Ради Європи «Зміцнення інформаційного суспільства в Україні» має на меті найбільш плідне вирішення комплексу проблем, що неодмінно виникають у інформаційному середовищі, а саме покращити свободу, різноманітність і плюралізм медіа, сприяти ефективності системи 
захисту персональних даних. Також програма спрямована на відкритий, всебічний і сталий підхід до управління інтернетом, що грунтується на правах людини і ставить іï в центр уваги. Крім того, програма сприятиме виконанню обов'язків і зобов'язань України перед Радою Європи, реалізаціï Угоди про асоціацію з ЄС і Плану дій з лібералізації ЄС візового режиму для України [1].

Отже, одне з головних застережень для правильного здійснення права на вільне вираження особистих думок це недопущення порушення суттєвих суспільних чи приватних інтересів. Свобода вираження поглядів є однією з головних підвалин демократичного суспільства, основною умовою його розвитку та самореалізації кожного з членів. Дотримуючись інших охоронюваних законом прав, свобода слова охоплює різні вияви інформації, позицій чи ідей, в тому числі і тих, що можуть ображати або шокувати. Це грунтується на вимогах плюралізму, толерантності та лібералізму, без яких немає демократичного суспільства.

Коли до особи, яка висловлює свої думки для запобігання порушенням інших прав чи усунення негативних наслідків, застосовуються певні обмеження, вони мусять тлумачитися суворо, і необхідність будь-якого втручання повинна бути переконливим чином встановлена. При цьому вирішальним елементом принципу необхідності втручання у право вільно виражати свою думку у демократичному суспільстві $€$ пропорційність владного впливу.

Саме із пропорційністю реагування тісно пов'язаний такий чинник обмеження права на вільне висловлювання як правило сумірності. Відповідно до нього для визнання обмеження свободи слова легітимним суд з урахуванням усіх обставин має переконатися, що суспільна важливість поширюваних відомостей не перевищує важливість охоронюваного у подібний спосіб інтересу, інакше кажучи, висвітлюване явище не $€$ питанням безперечної громадської важливості.

Владні органи мусять також довести, що поширення певної інформації та думок 3 переконливістю матиме значні негативні наслідки, тяжкість яких перевищуватиме позитив від оприлюднення відомостей. Коли ж конкретне вираження поглядів становить важливий громадський інтерес, то цей факт здебільшого має трактуватися на користь пріоритету інформаційного права.

Саме принцип пропорційності відіграє ключову роль для встановлення «справедливого балансу» суспільних та державних інтересів, обмеження свобод, що гарантуються конвенцією, мають бути адекватними законній меті, для якої застосовуються ці обмеження [2]. Втручання у право особи на свободу вираження поглядів буде порушенням статті $10 \mathrm{KoH}-$ венціі, якщо воно не підпадатиме під одне $з$ виключень, встановлених пунктом 2 статті 10 конвенціі.

Вплив держави у коментоване право у вигляді будь-якого обмеження буде правомірним, коли він необхідний за певних обставин. При цьому прикметник «необхідний» у розумінні пункту 2 статті 10 конвенції передбачає існування «нагальної суспільної потреби». При здійсненні оцінки, чи існує така необхідність, договірні держави користуються певною свободою розсуду. Проте вона супроводжується європейським наглядом, що стосуються одночасно закону і рішень, які його застосовують, навіть коли вони лунають з боку незалежного органу.

Суд має юрисдикцію винести рішення, щоб встановити, чи поєднується саме втручання та його зміст зі свободою вираження поглядів. При здійсненні свого повноваження по контролю суд повинен розглянути втручання в світлі всієї справи, включно 3 отриманням зауважень заявника та контекстом, в якому він їх зробив. 
Зокрема, необхідно встановити, чи було втручання пропорційним до законної переслідуваної мети і чи були доводи, наведені національними властями в його виправдання, достатніми і відповідними критеріями пункту 2 статті 10 конвенції. Здійснюючи це, суд повинен переконатися в тому, що національні органи влади застосували правила, які будуть відповідати принципам, закріпленим у статті 10, на прийнятній оцінці фактів, що належать до справи [3, п. 30].

За правилами, розробленими ЄСПЛ, при визнанні обмеження пропорційним воно повинне бути передбачене законом, відповідати принципам передбачуваності та прозорості; переслідувати одну 3 цілей, передбачених конвенційною статтею 10 , а також бути необхідним і найменш обмежуючим для досягнення відповідної цілі. Для досягнення результату (визначення справедливості обмеження інформаційного права) необхідно по черзі розглянути, чи було втручання у цій справі «встановлено законом», чи переслідувало воно цілі, які $є$ легітимними відповідно до пункту 2 статті 10 , чи було воно «необхідним у демократичному суспільстві» для досягнення зазначеної мети [4].

Першою правовою засадою правомірності втручання $€$ вимога, щоб воно було здійснене на законних підставах. Насамперед це означає, що фраза «відповідно до закону» вимагає, щоб оскаржуваний захід мав певне підгрунтя в національному праві [5, п. 60]. Яке значення вкладає у це поняття Європейський суд 3 прав людини? Якщо підходити 3 формального погляду, то для визначення правомірності обмеження за критерієм «встановлене законом» досить мати як законодавчу підставу для такого обмеження нормативний акт, який: 1) може розглядатися як «закон»; 2) прийнятий належним суб'єктом; 3) офіційно оприлюднений i набув чинності; 4) на момент застосу- вання не був скасований чи змінений у частині, що стосується конкретної справи [6, с. 54]. Такого переліку умов не досить, щоб забезпечити дієвість та ефективність юридичної норми.

За принциповою позицією суду вираз «відповідно до закону» вимагає не лише, щоб відповідний обмежувальний захід мав певну підставу в національному законодавстві. Він також стосується якості відповідного законодавства і вимагає, щоб воно було доступне особі, яка, крім того, повинна бути здатна передбачити його наслідки для себе, а також це законодавство повинно відповідати принципу верховенства права [7, п. 153; 8, п. 26]. Інакше кажучи, відбувається певне розмежування категорій «право» i «закон», при цьому їхнє практичне співвідношення схиляється до того, що «закон» дедалі частіше розуміють не як закон у строгому, спеціальному сенсі (як акт верховної влади і джерело вищої юридичної сили), а як офіційне джерело юридичних норм [9, с. 3].

Правила про належну поведінку особи при здійсненні нею діяльності щодо публічного поширення своїх ідей та думок не завжди можуть регулюватися на рівні акту, що має буквальне значення закону. В коментованій царині формуючими $є$ й інші суспільно значимі державні документи, а також так зване неписане право, традиції та звичаї. Формулювати закони з абсолютним ступенем визначеності в цій області буває важко, тому деяка гнучкість може бути допущена і навіть бажана, щоб дозволити національним судам розвивати право в світлі їх уявлень про те, які заходи є необхідними в інтересах справедливості [10, п. 33].

Ще одним чинником, дотримання якого покликане гарантувати обгрунтованість втручання, є той, що обмеження права повинне переслідувати законну ціль. Перелік цих цілей у частині 2 статті 10 ЄСПЛ є виключним у тому розумінні, що жодна інша 
ціль не вважається законною підставою для обмеження свободи самовираження. Звісно, будь-яке втручання та обмеження права особи публічно висловлювати свої погляди та ідеї може бути обгрунтоване такими причинами як захист національної безпеки або охорона прав інших осіб. Але завданням суду $є$ ретельне з'ясування того, чи дійсно вказані інтереси зазнавали загрози чи посягання, чи була мета їхнього захисту легітимною.

Прикладом подібної діяльності є справа «Далбан проти Румунії. За ії фабулою заявник, який працював журналістом, опублікував у своєму журналі статтю про низку шахрайських діянь, які, за його словами, вчинив пан Г. С. - головний виконавчий директор румунської державної сільськогосподарської компанії. Ця стаття та інша, яка вийшла пізніше, також кидають тінь підозри на сенатора Р. Т.

Заявник стверджував, що в основу опублікованої інформації було покладено доповіді Групи боротьби з шахрайством. Румунські суди визнали пана Далбана винним у наклепі, який карається відповідно до кримінального законодавства, та засудили його до трьох місяців ув'язнення (умовно). Також було присуджено сплатити панові Г. С. і панові Р. Т. компенсацію у розмірі 300000 румунських лей.

Вирішуючи справу по суті, ЄСПЛ встановив, що статті, у зв'язку з опублікуванням яких заявник був звинувачений, стосувалися питань, що становлять суспільний інтерес: управління державним майном, дії політиків щодо виконання покладених на них функцій. Перша стаття містила інформацію, взяту з матеріалів проведеного Відділом поліції по боротьбі 3 економічними злочинами розслідування відносно керівництва агрокомпанії, у якій Г. С. був виконавчим директором, а Р. Т. - представником держави.

У другій статті йшлося про оклад, який отримував сенатор Р. Т. відповідно до його посади у Спостережній раді, використання ним службового автомобіля. Суд основну увагу зосередив на вивченні питання, чи відповідало втручання законній меті «захисту репутації інших осіб».

Було вказано, що в таких справах межі державної оцінки окреслюються інтересами демократичного суспільства у тому, щоб преса мала можливість виконувати свою роль «сторожового пса» та надавати інформацію, яка становить значний громадський інтерес. Неприпустимо позбавляти журналіста можливості висловлювати критичні судження, якщо він не може довести їх правдивість.

Суд також зазначив, що немає жодних доказів того, що опис подій, наведених у статтях, був абсолютно неправдивим і був розроблений для розпалу дискредитації проти Г. С. i сенатора Р. Т. Пан Далбан писав не про аспекти приватного життя P. Т., а про свою поведінку та ставлення до нього як до обраного представника народу. Національний суд визнав, що заявник висловив свою думку щодо практики сенатора та того, як останній виконував свої обов'язки, не відображаючи реальності i, отже, викликав наклеп. Такий висновок було зроблено без дослідження доказів, наданих заявником і без урахування меж толерантності посадових осіб до ї критики, яка має бути підвищеною. Тому має місце порушення статті 10 конвенції [11, п. 48, 50].

Третя вимога до застосування обмежень у праві на висловлювання: подібний захід має бути дійсно необхідним у демократичному суспільстві для забезпечення однієї з законних цілей. Інакше кажучи, втручання, навіть за умови його законності та відповідності легітимній цілі, може бути визнане невиправданим, якщо воно не $є$ суспільно прийнятним. Застосування в такому контексті принципу пропорційності означає, що в демократичному суспільстві правомірне втручання повинно бути відповідним 
не лише легітимній меті, а й базуватися на адекватній і необхідній реакціï національних правозастосовних органів.

Причини, якими держава виправдовує накладення обмежень, повинні бути «відповідними і достатніми», а обмеження - сумірними цілям, що переслідуються. Звісно, визначення критеріїв необхідності запровадження тих чи інших засобів державного втручання $€$ прерогативою національних владних інституцій. В межах реалізаціï наданих йому контрольних функцій суд у своїй прецедентній практиці напрацював низку підходів для оцінки необхідності втручання у інформаційне право. Зазначені суспільні чинники, будучи оціночними характеристиками, мають розглядатися саме в контексті необхідності втручання у демократичному суспільстві.

Зазначений чинник, на відміну від двох попередніх, не має абсолютних критеріїв і ознак, а мусить враховуватися з огляду на загальну демократичну традицію в конкретному соціумі. Досить часто, посилаючись якраз на невідповідність застосовуваних державою обмежень, ЄСПЛ визнає втручання у право на публічне вираження поглядів неадекватним.

Як приклад може слугувати справа «Бладет Тромсе і Стенсаас проти Норвегії», де йшлося про незаконність звинувачення науковця, який опублікував відомості про варварські методи полювання на тюленів і цим наніс шкоду честі і гідності мисливців. У цій справі Європейський суд не встановив, що безсумнівний інтерес членів екіпажу до захисту їхньої репутації був достатнім для переважання життєво-важливих інтересів громадськості щодо забезпечення усвідомленої публічної дискусії з питань місцевого та національного, а також міжнародного інтересу.

Причини, на які посилається держава-відповідач, хоча і актуальні, але $€$ не достатніми для того, щоб показати, що втручання, на яке скаржи- лися, було «необхідним у демократичному суспільстві». Незважаючи на свободу оцінювання національних органів влади, суд вважає, що не було розумного співвідношення пропорційності між обмеженнями, які ставили право заявників на свободу вираження поглядів, і законною метою, яку переслідували. Тому суд вважає, що було порушення статті $10 \mathrm{конвен-}$ ції [12, п. 70].

3 проведеного дослідження можна зробити певні висновки. Право вільно та безперешкодно виражати свої міркування, погляди та переконання $€$ одним із основоположних для кожної людини. Це також стосується публічного оприлюднення своїх думок. Реалізація цього права не повинна бути пов'язана з порушенням охоронюваних державних, суспільних інтересів або приватних прав конкретної людини. Тому в окремих, чітко встановлених законом випадках можливий державний контроль за свободою слова, але тільки у разі існування чітко зумовленої суспільної потреби. За правилами, напрацьованими Європейським судом з прав людини, втручання у свободу вираження поглядів (обмеження) є допустимим, якщо воно встановлене законом i $€$ необхідним у демократичному суспільстві.

Ця наукова стаття присвячена дослідженню актуального питання про забезпечення належного механізму здійснення основоположного права людини на вільне вираження особистих поглядів та ідей. Відстоюється теза, що вказане право формує засади реалізаціі інших прав, але воно не є безменним.

Обмеження права на вільне вираження поглядів не є порушенням конвенції, якщо иі обмеження встановлені для досягнення однієї з иілей, зазначених у пункті 2 cmammi 10 иього міннародного акту. Втім, засоби державного втручання у свободу слова завжди мають бути чітко визначені, 
повинні встановлюватися критеріі та межі подібного владного впливу.

У роботі наголошується на необхідності дотримання суспільного балансу тих протилежних за сутністю $і$ змістом суспільних та приватних інтересів, які при иьому стикаються. Це публічний інтерес у самовираженні кожної особи, який реалізується через можливість суб'єкта доводити до відома оточуючих свої політичні та інші переконання, думки, ідеї, та державні інтереси щодо охорони конфіденційної інформації і публічного порядку, а також права громадян на приватність.

Проаналізовані правові підходи Європейського суду з прав людини в царині напрацювання критеріїв правомірності обмежень права на свободу вираження поглядів, що накладаються органами державної влади. Доводиться, що вирішальним елементом принциипу необхідності втручання в право вільно виражати свою думку у демократичному суспільстві $\epsilon$ пропориійність владного впливу. Саме принщип пропориійності відіграє ключову роль для встановлення «справедливого балансу» суспільних та державних інтересів. Обменення свобод, що гарантуються конвенцією, мають бути адекватними законній меті, для якої застосовуються изі обмеження.

Будь-яке втручання у свободу слова повинне за загальним правилом бути встановлене законом, відповідати принципам передбачуваності та прозорості; переслідувати одну з иілей, передбачених конвениійною статтею 10 , а також бути необхідним і найменш обмежуючим для досягнення відповідної цілі. Для досягнення результату (визначення справедливості обмеження інформаційного права) слід довести, що воно «е необхідним у демократичному суспільстві» для досягнення легітимної мети.

Ключові слова: свобода слова, обмеження права, вираження поглядів.
Guyvan P. Adherence to European principles of proportionality is the main principle of guaranteeing the right to free self-expression

This scientific article is devoted to the study of the topical issue of providing an appropriate mechanism for the exercise of the fundamental human right to free expression of personal views and ideas. The thesis is defended that the specified right forms bases of realization of other rights. However, it is not unlimited.

Restrictions on the right to freedom of expression shall not constitute a violation of the Convention if those restrictions are established in order to achieve one of the purposes set forth in article 10, paragraph 2, of this international act. However, the means of state intervention in freedom of speech must always be clearly defined, the criteria and limits of such power influence established. The paper emphasizes the need to maintain the social balance of those opposite in essence and content of public and private interests, which thus collide.

This is the public interest in the self-expression of each person, which is realized through the ability of the subject to inform others of their political and other beliefs, opinions, ideas, on the one hand, and state interests in protecting confidential information and public order, and citizens' right to privacy. The legal approaches of the European Court of Human Rights in the field of developing criteria for the legality of restrictions on the right to freedom of expression imposed by public authorities are analyzed.

It turns out that the decisive element of the principle of the need to intervene in the right to freely express one's opinion in a democratic society is the proportionality of power. It is the principle of proportionality that plays a key role in establishing a "fair balance" of public and state 


\section{ЮРИАИЧНИЙ ВІСНИК, 2020/3}

interests. Restrictions on the freedoms guaranteed by the Convention must be adequate to the legitimate aim for which those restrictions apply.

Any interference with freedom of expression must, as a general rule, be established by law, comply with the principles of predictability and transparency; pursue one of the objectives set out in Article 10 of the Convention, and be necessary and least restrictive to achieve that objective. Therefore, in order to achieve the result - determining the fairness of the restriction of information law must be proved, it is "necessary in a democratic society" to achieve a legitimate goal.

Key words: freedom of speech, restriction of law, expression of views.

Література

1. Council of Europe office in Ukraine. URL: http://wrw.coe.int/en/web/ kyiv/41.

2. Шевчук C. Європейська конвенція про захист прав людини та основних свобод: практика застосування та принщипи тлумачення у контексті сучасного украінського праворозуміння. URL: http:// eurocourt.in.ua / Article.asp? AIdx $=416$.

3. Рішення ЕСПЛ від 21 січня 1999 року у справі «Яновський проти Польщзі» (Janowski v. Poland), заява № 25716/94. URL: https://mmdc.ru/ praktika_evropejskogo_suda/praktika_ po_st10_evropejskoj_konvencii/europ_ practice64/.

4. Рішення ЕСПЛ від 26 квітня 1979 року у cnpaвi "Sunday Times $v$. the United Kingdom", заява № 6538/74.
URL: $\quad$ https://cedem.org.ua/library/ sprava-sandi-tajms-proty-spoluchenogokorolivstva-2/.

5. Рішення ЕСПЛ від 29 червня 2006 року у справі «Пантелеєнко проти України», заява № 11901/02. URL: https://zakon.rada.gov.ua/laws / show /974_274\#Text.

6. Матвеева Ю.І. Приниип визначеності в рішеннях Європейського суду з прав людини. Наукові записки Національного університету «Києво-Могилянська академія». 2008. T. 77. С. 53-56.

7. Рішення ЕСПЛ від 29 квітня 2003 року у справі «Полторацький проти України» заява № 38812/97. URL: https: / / zakon.rada.gov.ua/laws / show/974_838\#Text.

8. Рішення ЕСПЛ від 24.04.90 у справі «Ювіг проти Франиї̈» (Huvig v. France), заява № 11105/84. URL: http:// www.hrcr.org / safrica / privacy / huvig_ france.html.

9. Оніщенко Н. Принщи законності: природа та сутність в умовах демократичних змін. Віче. 2012. № 12. С. 2-4.

10. Рішення ЕСПЛ віО 27 березня 1996 року у справі «Гудвін проти Сполученого Королівства» (Goodwin v. The United Kingdom), заява № 17488/90. URL: $\quad$ https: / / hudoc.echr.coe.int / fre\#\{«itemid»: [«001-57974»]\}.

11. Рішення ЕСПЛ від 29.09.1999 у справі "Далбан проти Румунії» (Dalban v. Romania), заява № 28114/95. URL: http: / / eurocourt.in.ua/Article.asp? AIdx $=97$.

12. Рішення ЕСПЛ віО 20 травня 1999 року у справі «Бладет Тромсе $і$ Стенсаас протии Норвегї) (Bladet Tromso and Stensaas v. Norway), заява № 21980/93. URL: https: // hudoc.echr.coe.int/eng\#\{ «itemid»:[«001-58369»]\}). 